\title{
Filamentous Fungi Isolates of Contaminated Sediment in the Amazon Region with the Potential for Benzo(a)pyrene Degradation
}

\author{
Hilton Marcelo de Lima Souza • Lara Durães Sette • Adolfo José da Mota • \\ Joaquim Ferreira do Nascimento Neto • André Rodrigues • Tássio Brito de Oliveira • \\ Fernando Mendes de Oliveira • Luiz Antônio de Oliveira • Hileia dos Santos Barroso • \\ Sandra Patricia Zanotto
}

Received: 25 April 2016 / Accepted: 27 September 2016 / Published online: 4 November 2016

(C) Springer International Publishing Switzerland 2016

\begin{abstract}
Filamentous fungi were isolated from contaminated sediment samples in the Amazon region of Brazil to select species with potential for benzo(a)pyrene $(\mathrm{BaP})$ degradation, a polycyclic aromatic hydrocarbon (PAH) with high molecular weight and known for its mutagenic and carcinogenic properties. The isolates were submitted to biodegradability test using 2.6-dichlorophenol indophenol (DCPIP), gallic acid reaction, and evaluation of $\mathrm{BaP}$ influence in the enzymatic (ligninolytic) activity. The selected fungi
\end{abstract}

H. M. de L. Souza $(\bowtie) \cdot$ F. M. de Oliveira

H. dos S. Barroso

Universidade do Estado do Amazonas, Escola Superior de

Ciências da Saúde, Av. Carvalho Leal, 1777, CEP

69065-170 Manaus, Amazonas, Brazil

e-mail: hilton_marcelo@hotmail.com

L. D. Sette · A. Rodrigues - T. B. de Oliveira

Universidade Estadual Paulista "Júlio de Mesquita Filho",

Campus de Rio Claro, Departamento deBioquímica e

Microbiologia Aplicada, IB/UNESP, Av. 24-a, 1515, CEP

13506-900 Rio Claro, São Paulo, Brazil

\begin{abstract}
A. J. da Mota · J. F. do Nascimento Neto - S. P. Zanotto Universidade Federal do Amazonas, Departamento de Ciências Fundamentais e DesenvolvimentoAgrícola (DCFDA) / Faculdade de Ciências Agrárias (FCA) e Centro de Apoio Multidisciplinar, Divisão deBiotecnologia, Av. General Rodrigo Octávio Jordão Ramos, 3000, CEP 69077-000 Manaus, Amazonas, Brazil
\end{abstract}

L. A. de Oliveira - S. P. Zanotto Instituto Nacional de Pesquisas da Amazônia (INPA), Av. André Araújo, 2.936, CEP 69067375 Manaus, Amazonas, Brazil were submitted to the taxonomic identification and used in biodegradation assays, which were carried out using gas chromatography coupled to mass spectrometry (GC-MS). A qualitative analysis of the presence of $\mathrm{BaP}$ metabolites that have recently been reported in literature was also performed by GC-MS. A total of 146 fungal isolates were recovered. Among them, $63.7 \%$ were positive for the redox indicator DCPIP. From these isolates, $22.6 \%$ showed positive responses to the gallic acid reaction. In enzymatic tests, the fungi Megasporoporia sp. S47 and unidentified Sordariales S69 presented highest activities of laccase and manganese peroxidase in the presence of BaP. Additionally, the white-rot fungus Megasporoporia sp. S47 showed better performance in $\mathrm{BaP}$ degradation (54\%). Therefore, Megasporoporia sp. S47, obtained from an environment with considerable PAH contamination, was selected as a promising genetic resource for application in new studies related to enzyme production and characterization and $\mathrm{BaP}$ degradation optimization.

Keywords Fungi $\cdot$ Ligninolytic enzymes .

Biodegradation · Polycyclic aromatic hydrocarbons .

Benzo(a)pyrene

\section{Introduction}

The polycyclic aromatic hydrocarbons (PAHs) are organic pollutants derived mainly from the burning of 
fossil fuels and waste from industrial activities (Almeida et al. 2007; Netto et al. 2000). Through pyrolysis, the molecules are disintegrated and their subsequent recombination can promote the formation of high molecular weight PAHs (HMW) consisting of four to eight aromatic rings fused together and known to be highly toxic (Haritash and Kaushik 2009).

The US Environmental Protection Agency (USEPA) has classified a group of 16 individual PAHs as priority pollutants in environmental studies. Among these, benzo(a)pyrene (BaP), a HMW HPA consists of five aromatic rings, is known for its mutagenic, carcinogenic, and teratogenic properties in mammals and aquatic organisms (IARC 1983; Juhasz and Naidu 2000; Jennings 2012). Because of its hydrophobicity, $\mathrm{BaP}$ tends to be associated with the particulate material, becoming one of the main xenobiotics that remaining deposited in soils and sediments for long periods. In the aquatic environment, they can be absorbed into the skin or by ingestion of animals, causing bioaccumulation and biomagnification by feeding along the trophic chain (Netto et al. 2000; Mackay and Fraser 2000; Perelo 2010). Thus, the presence of this contaminant can be a threat to different environments and their biota.

Due to the high chemical stability in BaP molecule, processes such as volatilization and photolysis are not efficent in the disintegration of this compound, as occurs naturally with low molecular weight PAHs. However, microbial degradation of PAHs is considered as an attractive biotechnological alternative (Cerniglia and Sutherland 2010; Perelo 2010). Filamentous fungi present some advantages in degradation process in comparison to bacteria and yeast, since they present mycelial growth, rapid branching and colonization of insoluble substrates, ability to tolerate high concentrations of toxic compounds and to grow under stressful conditions. The white-rot basidiomycetes (ligninolytic fungi) are considered the best group of fungi for environmental pollutants degradation, since they are able to produce a range of extracellular oxidoreductases with nonspecific activities associated with intracellular monooxygenases that can mineralize the pollutant and/or transform it into less toxic compounds (Lemos et al. 2008; Haritash and Kaushik 2009; Harms et al. 2011). Due to the various attributes mentioned, filamentous fungi can be considered as important components for biotechnological models of bioremediation of environments contaminated with PAHs.
Several species of fungi with abilities to degrade PAH were reported in the literature, including ligninolytic and non-ligninolytic strains. Among the non-ligninolytic fungi, Aspergillus ochraceus, Cunninghamella elegans, and Cunninghamella echinulata were mentioned as able to degrade phenanthrene, fluoranthene, pyrene, chrysene, and benzo(a)pyrene (Cerniglia 1992; Muncnerová and Augustin 1994), Aspergillus sclerotiorum and Mucor racemosus as able to degrade pyrene and benzo(a)pyrene (Ravelet et al. 2000; Passarini et al. 2011a), and Penicillium sp. and Trichoderma harzianum as efficient in benzo(a)pyrene degradation (Machín-Ramírez et al. 2010). Among the ligninolytic fungi, particularly white-rot fungi, Phanerochaete chrysosporium, Bjerkandera sp., and Trametes versicolor are cited as excellent degraders of low and high molecular weight PAHs, and there are information related to PAHs mineralization by $P$. chrysosporium (Muncnerová and Augustin 1994; Lemos et al. 2008). Other genera of basidiomycetes such as Anthracophyllum, Armillaria, and Polyporus are also cited as promising in benzo(a)pyrene degradation (Acevedo et al. 2011; Hadibarata and Kristanti 2012a, b).

One of the strategies used to select fungi with potential in bioremediation is isolation that comes from sites contaminated with petroleum products and PAHs. Soils and sediments are an excellent source of microorganisms that retain high tolerance, since these environments are selective for the pollutant adapted fungi (Volkering and Breure 2003; Colla et al. 2008; Zafra et al. 2014). Environmental contamination with PAHs has been reported by several researchers in Brazil revealing high concentrations of these compounds in river, dam, and estuary sediment (Brito et al. 2005; Bícego et al. 2006; Meire et al. 2008; Leite et al. 2011). Recently, a research study conducted with sediment samples from the Negro River in the Amazon showed that $70 \%$ of the total abundance of priority PAHs were classified as high molecular weight, such as chrysene, BaP, benzo(a)anthracene, and dibenzo(a,h)anthracene (Souza et al. 2015).

After the isolation of fungal strains from the contaminated environment, the use of phenolic oxidation (gallic acid, guaiacol) and hydrocarbon oxidoreduction indicators, Remazol Brilliant Blue R discoloration, PAHs tolerance tests, ligninolytic activities, and biodegradation experiments is some of the major methods employed 
successfully to obtain fungi of interest in bioremediation (Hanson et al. 1993; Conceição et al. 2005; Passarini et al. 2011a, b; Hadibarata and Kristanti, 2012a, b; Argumedo-Delira et al. 2012; Bonugli-Santos et al. 2012; Lee et al. 2014). In the Amazon region, the existence of research studies that involve the isolation and selection of microorganisms in contaminated areas with a view to bioprospecting and bioremediation is still largely incipient. Thus, taking into consideration the presented context, this paper aims to select filamentous fungi isolated from sediments from an Amazon region that is contaminated with PAHs, and with potential for benzo(a)pyrene degradation.

\section{Material and Methods}

\subsection{Isolation of Filamentous Fungi from Contaminated Sediments}

The fungal isolates were obtained from surface sediment samples from the Negro River, Amazonas State, Brazil, in six different locations: close to the Tupé Sustainable Development Reserve (TR), the mouth of the São Raimundo basin (SR), Modern Manaus Port (MM), Panair Port (PA), Iranduba (IR) on the right bank of the river, and Ceasa Port region (CE). All locations were characterized by having different levels of PAHs contamination, as described by Souza et al. (2015) (Table 1). Fungal isolation was performed by serial suspension technique, based on Gomes et al. (2011) in which $25 \mathrm{~g}$ of sediment samples were diluted in $225 \mathrm{~mL}$ of sterile distilled water and further dilutions (1:1000) were performed seeding $1 \mathrm{~mL}$ in petri plates containing Sabouraud Dextrose Agar (SDA; $40 \mathrm{~g} \mathrm{~L}^{-1}$ dextrose, $10 \mathrm{~g} \mathrm{~L}^{-1}$ mycological peptone, and $15 \mathrm{~g} \mathrm{~L}^{-1}$ agar) supplemented with chloramphenicol $\left(100 \mathrm{mg} \mathrm{L}^{-1}\right)$ in quadruplicate. The inoculated plates were incubated at $28^{\circ} \mathrm{C}$ for 5 days and purified isolates were preserved in vials containing sterile distilled water (Castellani 1939) and cryopreservation tubes at $-20{ }^{\circ} \mathrm{C}$.

\subsection{Biodegradability Test Using the 2.6-Dichlorophenol Indophenol}

The use of redox indicator 2.6-dichlorophenol indophenol (DCPIP) has enabled us to understand bacteria's ability to degrade diesel hydrocarbons (substrate) through redox reactions. In this study, the method of
Hanson et al. (1993) was adapted to evaluate the ability of fungal cultures to oxidize hydrocarbons and reduce the DCPIP indicator. Therefore, we used the liquid medium Bushnell-Hass (BH), consisting of $\mathrm{KH}_{2} \mathrm{PO}_{4}$ $(1.0 \mathrm{~g} / \mathrm{L}) ; \mathrm{K}_{2} \mathrm{HPO}_{4}(1.0 \mathrm{~g} / \mathrm{L}) ; \mathrm{NH}_{4} \mathrm{H}_{2} \mathrm{PO}_{4}(1.0 \mathrm{~g} / \mathrm{L})$; $\mathrm{MgSO}_{4} .7 \mathrm{H}_{2} \mathrm{O}(0.010 \mathrm{~g} / \mathrm{L}) ; \mathrm{FeCl}_{2} .4 \mathrm{H}_{2} \mathrm{O}(0.05 \mathrm{~g} / \mathrm{L})$; $\mathrm{CaCl}_{2} \cdot 2 \mathrm{H}_{2} \mathrm{O}(0.020 \mathrm{~g} / \mathrm{L})$, distilled water $(1000 \mathrm{~mL})$, $\mathrm{pH}$ 7.0. After sterilization at $121{ }^{\circ} \mathrm{C}$ for $15 \mathrm{~min}$, $0.010 \mathrm{~g} / \mathrm{L}$ of the redox DCPIP indicator was added. In test tubes (triplicate) $3000 \mu \mathrm{L}$ of the liquid medium was added, $30 \mu \mathrm{L}$ of diesel oil (filtered in Millipore membrane $0.22 \mu \mathrm{m}$ ) and culture plugs ( $7 \mathrm{~mm}$ diameter) from the edge of the colony to each fungi after 7 days of culture. The tubes were put into an incubator under agitation at $180 \mathrm{rpm}$ and $30{ }^{\circ} \mathrm{C}$ for $48 \mathrm{~h}$. The color change of the (DCPIP) indicator from blue (oxidized form) to transparent (reduced form) was monitored at three different times: within $2 \mathrm{~h}$, after 24 and $48 \mathrm{~h}$.

\subsection{Gallic Acid Reaction}

The fungal isolates that showed positive responses to the redox DCPIP indicator were subjected to the 3,4,5trihydroxybenzoic acid oxidation test (gallic acid), which is characterized by the presence of a brown halo around the mycelium, indicating the formation of quinones. This technique has been applied to select fungi able to produce phenoloxidase enzymes that may be directly involved in xenobiotic degradation, such as PAHs (Conceição et al. 2005; Erden et al. 2009). Therefore, the isolates were inoculated on Petri plates containing Potato Dextrose Agar (PDA; $4 \mathrm{~g} \mathrm{~L}^{-1}$ potato broth, $20 \mathrm{~g} \mathrm{~L}^{-1}$ Dextrose $15 \mathrm{~g} \mathrm{~L}^{-1}$ agar) and incubated for 7 days at $28{ }^{\circ} \mathrm{C}$. After this period, three fungal culture plugs $(0.5 \mathrm{~cm}$ diameter $)$ from the edge of the colonies were transferred to plates containing Extract Malt $2 \%$ (MEA $2 \% ; 20 \mathrm{~g} \mathrm{~L}^{-1}$ of malt extract, $15 \mathrm{~g} \mathrm{~L}^{-1}$ agar), supplemented with gallic acid $0.5 \%$ and incubated for 5 days at $28^{\circ} \mathrm{C}$. The experiments were conducted in triplicate. In cultures with positive responses, the intensity of the halo color was recorded and classified as described by Lee et al. (2014): DB (dark brown), BR (brown), and YB (yellowish brown).

\subsection{Influence of the Presence of Benzo(a)pyrene in Ligninolytic Enzyme Production}

The isolates of filamentous fungi that were able to oxidize gallic acid were submitted to in vitro assays to 
Table 1 Sampling sites of surface sediments with different levels of contamination by polycyclic aromatic hydrocarbons (PAHs) and in different locations of the Negro River, Amazon, Brazil (available in Souza et al. 2015)

\begin{tabular}{|c|c|c|c|c|c|}
\hline Locations & Sampling sites & Geographical position & Granulometry & $\Sigma \mathrm{PAH}\left(\right.$ ng g $\left.^{-1}\right)$ & $\Sigma 16$ PAH $\left(\right.$ ng g $\left.^{-1}\right)$ \\
\hline \multirow{3}{*}{$\begin{array}{l}\text { Tupé Sustainable Development } \\
\text { Reserve }\end{array}$} & TR1 & $\mathrm{S} 03^{\circ} 03^{\prime} 02.6^{\prime \prime} \mathrm{W} 060^{\circ} 15^{\prime} 24.0^{\prime \prime}$ & Sand & 22.6 & 9.1 \\
\hline & TR2 & $\mathrm{S} 03^{\circ} 03^{\prime} 04.7^{\prime \prime} \mathrm{W} 060^{\circ} 15^{\prime} 23.9^{\prime \prime}$ & Sand & nd & nd \\
\hline & TR3 & $\mathrm{S} 03^{\circ} 03^{\prime} 06.9^{\prime \prime} \mathrm{W} 060^{\circ} 15^{\prime} 25.1^{\prime \prime}$ & Sand & 6.5 & 6.5 \\
\hline \multirow[t]{3}{*}{ Bacia do São Raimundo } & SR1 & $\mathrm{S} 03^{\circ} 07^{\prime} 55.2^{\prime \prime} \mathrm{W} 060^{\circ} 02^{\prime} 05.3^{\prime \prime}$ & Mud & 5273.8 & 1187 \\
\hline & SR2 & $\mathrm{S} 03^{\circ} 08^{\prime} 05.45^{\prime \prime} \mathrm{W} 060^{\circ} 01^{\prime} 53.02^{\prime \prime}$ & Sand & 138.4 & 56.4 \\
\hline & SR3 & $\mathrm{S} 03^{\circ} 08^{\prime} 01.55^{\prime \prime} \mathrm{W} 060^{\circ} 01^{\prime} 58.30^{\prime \prime}$ & Sand & 2460.5 & 1354 \\
\hline \multirow[t]{3}{*}{ Manaus Moderna Port } & MM1 & $\mathrm{S} 03^{\circ} 08^{\prime} 34.88^{\prime \prime} \mathrm{W} 060^{\circ} 01^{\prime} 20.30^{\prime \prime}$ & Sand & 299.5 & 133 \\
\hline & MM2 & $\mathrm{S} 03^{\circ} 08^{\prime} 35.5^{\prime \prime} \mathrm{W} 060^{\circ} 01^{\prime} 21.4^{\prime \prime}$ & Sand & 272.9 & 182 \\
\hline & MM3 & $\mathrm{S} 03^{\circ} 08^{\prime} 28.1^{\prime \prime} \mathrm{W} 060^{\circ} 01^{\prime} 28.9^{\prime \prime}$ & Sand & 1265.8 & 601 \\
\hline \multirow[t]{3}{*}{ Panair Port } & PA1 & $\mathrm{S} 03^{\circ} 08^{\prime} 49.2^{\prime \prime} \mathrm{W} 060^{\circ} 00^{\prime} 42.4^{\prime \prime}$ & Mud & 892.7 & 250 \\
\hline & PA2 & $\mathrm{S} 03^{\circ} 08^{\prime} 46.64^{\prime \prime} \mathrm{W} 060^{\circ} 00^{\prime} 40.50^{\prime \prime}$ & Mud & 995.5 & 232 \\
\hline & PA3 & $\mathrm{S} 03^{\circ} 08^{\prime} 43.65^{\prime \prime} \mathrm{W} 060^{\circ} 00^{\prime} 44.49^{\prime \prime}$ & Sand & 358.2 & 72.1 \\
\hline \multirow[t]{3}{*}{ Iranduba } & IR1 & $\mathrm{S} 03^{\circ} 09^{\prime} 36.2^{\prime \prime} \mathrm{W} 060^{\circ} 02^{\prime} 10.8^{\prime \prime}$ & Mud & 22.8 & 5.6 \\
\hline & IR2 & $\mathrm{S} 03^{\circ} 09^{\prime} 14.2^{\prime \prime} \mathrm{W} 060^{\circ} 02^{\prime} 59.8^{\prime \prime}$ & Mud & 142.5 & 116 \\
\hline & IR3 & $\mathrm{S} 03^{\circ} 08^{\prime} 49.9^{\prime \prime} \mathrm{W} 060^{\circ} 04^{\prime} 10.8^{\prime \prime}$ & Mud & 50.2 & 35.2 \\
\hline \multirow[t]{3}{*}{ Ceasa Port } & CE1 & $\mathrm{S} 03^{\circ} 08^{\prime} 06.7^{\prime \prime} \mathrm{W} 059^{\circ} 56^{\prime} 17.4^{\prime \prime}$ & Mud & 2375.3 & 407 \\
\hline & CE2 & $\mathrm{S} 03^{\circ} 08^{\prime} 08.15^{\prime \prime} \mathrm{W} 059^{\circ} 56^{\prime} 16.04^{\prime \prime}$ & Sand & 437.6 & 163 \\
\hline & CE3 & $\mathrm{S} 03^{\circ} 08^{\prime} 04.0^{\prime \prime} \mathrm{W} 059^{\circ} 56^{\prime} 11.2^{\prime \prime}$ & Mud & 1113.8 & 529 \\
\hline
\end{tabular}

$n d$ not detected

evaluate the influence of $\mathrm{BaP}$ on the production of ligninolytic enzymes. The fungal isolates were grown in petri dishes containing $2 \%$ MEA and were incubated for 7 days at $28{ }^{\circ} \mathrm{C}$. After this period, three fungal culture plugs $(7 \mathrm{~mm}$ diameter) from the edge of the colonies were transferred to Erlenmeyer flasks of $125 \mathrm{~mL}$ containing $50 \mathrm{~mL}$ of broth Extract Malt $2 \%$ (MEB2; $20 \mathrm{~g} \mathrm{~L}^{-1}$ of malt extract, $1000 \mathrm{~mL}$ distilled water) in quadruplicate. The flasks were incubated with agitation for $72 \mathrm{~h}$ at $150 \mathrm{rpm}$ and $30^{\circ} \mathrm{C}$ for each isolate. Then, a duplicate of each isolate was supplemented with $2 \mathrm{mg}$ of BaP (Sigma-Aldrich, $99 \%$ ) (St. Louis, MO, USA) dissolved in $0.5 \mathrm{ml}$ of dimethylformamide and the other flasks remained without $\mathrm{BaP}$ supplementation. The flasks were again incubated for 7 days under the same conditions described above. The enzymatic broth was obtained by vacuum filtered and centrifugation at $7830 \mathrm{rpm}$ for $45 \mathrm{~min}$ (Eppendorf Centrifuge 5430R). The resulting supernatant was used as enzyme source.

The activity of laccase, lignin peroxidase (LIP), and manganese peroxidase $(\mathrm{MnP})$ was measured spectrophotometrically (Biochrom Libra S60, Cambridge, England) in triplicate, through the absorbance difference calculation $(\Delta \mathrm{Abs}=$ Initial Abs - Final Abs $)$. One enzyme unit was defined as $1.0 \mu \mathrm{mol}$ of product formed per minute under the assay conditions. Laccase activity was determined by the oxidation of 2.2-azino-bisethylbenzthiazoline (ABTS) through monitoring the increase in absorbance at $420 \mathrm{~nm}$ as described by Buswell et al. (1995). The mixture was composed of $300 \mu \mathrm{L}$ sodium acetate buffer $(0.1 \mathrm{M}, \mathrm{pH} 5.0), 600 \mu \mathrm{L}$ of enzyme solution and $100 \mu \mathrm{L}$ ABTS solution $(0.03 \%$ $w / v)$. The mixture was incubated at $37^{\circ} \mathrm{C}$ for $10 \mathrm{~min}$. LIP activity was determined by the oxidation of veratryl alcohol through monitoring the increase in absorbance at $310 \mathrm{~nm}$ as described by Arora and Gill (2001). The mixture was composed of $600 \mu \mathrm{L}$ enzyme solution, $200 \mu \mathrm{L}$ of veratryl alcohol $(2 \mathrm{mM})$ in sodium tartrate buffer $(0.4 \mathrm{M}, \mathrm{pH} 4.5)$ and $200 \mu \mathrm{L}$ of hydrogen peroxide (2 $\mathrm{mM})$. The reaction was initiated with hydrogen peroxide and the mixture was incubated for $10 \mathrm{~min}$. The MnP activity was determined by oxidation of $\mathrm{Mn}^{2+}$ to $\mathrm{Mn}^{3+}$ and formation of the malonate complex $\mathrm{Mn}^{3+}$, which was accompanied by an increase in absorbance at $270 \mathrm{~nm}$, according to Giardina et al. (2000). The reaction mixture contained $800 \mu \mathrm{L}$ of 
sodium malonate buffer ( $50 \mathrm{mM}, \mathrm{pH} 4.5), 50 \mu \mathrm{L}$ $\mathrm{MnSO}_{4}(10 \mathrm{mM}), 100 \mu \mathrm{L}$ of enzyme solution and $50 \mu \mathrm{L}$ of hydrogen peroxide $(2 \mathrm{mM})$. The reaction was initiated with hydrogen peroxide, acting as a cofactor for enzymes. The mixture was incubated at room temperature for $5 \mathrm{~min}$.

\subsection{Molecular Identification of Selected Fungal Isolates}

The selected isolates (S47 and S69) were identified by molecular taxonomy. Genomic DNA from 7-day growth cultures was extracted by physical lysis with glass beads (425-600 $\mu \mathrm{m}$ diameter) following a combined protocol from Moeller et al. (1992) and Gerardo et al. (2004). After DNA extraction, the ITS region was amplified with the primer pair ITS4 and ITS5 for isolate S69 and ITS1 (White and Lee 1990) and UniR (MähnB et al. 2005) for isolate S47. Amplification reactions consisted of $0.2 \mathrm{mM}$ of each dNTP, $5 \times \mathrm{KCl}$ buffer, $1.5 \mathrm{mM} \mathrm{MgCl}_{2}, 0.5 \mu \mathrm{M}$ of each primer and $1 \mathrm{U}$ of Taq polymerase (Promega) in a final volume of $25 \mu \mathrm{L}$. Amplicon purification was performed using the Wizard ${ }^{\circ}$ SV Gel and PCR Clean-up System kit (Promega) and quantified in the NanoDrop ${ }^{\circledR}$ (Thermo Scientific). DNA sequencing was performed using the BigDye ${ }^{\circledR}$ Terminator Cycle Sequencing kit v.3.1 (Life Technologies) according to the manufacturer's protocol. Forward and reverse sequences were compiled in contigs in BioEdit v7.1.3. The contigs were queried in the NCBIGenBank (www.ncbi.nlm.nih.gov) of the Fungal Biodiversity Centre (CBS, www.cbs.knaw.nl) databases for homologous sequences of closely related species.

\subsection{Benzo(a)pyrene Biodegradation}

The biodegradation assays were based on the method proposed by Passarini et al. (2011a) and performed according to the cultivation, inoculation, and incubation methodology described in item 2.4. After $72 \mathrm{~h}$ of incubation, $125 \mathrm{~mL}$ Erlenmeyer flasks containing $30 \mathrm{~mL}$ of MEB2 were supplemented with $1 \mathrm{mg}$ of $\mathrm{BaP}$ (Assay I) and $2 \mathrm{mg}$ of $\mathrm{BaP}$ (Assay II), diluted in $0.5 \mathrm{~mL}$ dimethylsulfoxide and incubated for 14 days. The experiments were performed in duplicate and the control group consisted of $2 \%$ MEB supplemented with BaP. Biodegradation quantification was conducted after 7 and 14 days of $\mathrm{BaP}$ supplementation in liquid medium.

\subsection{Extraction and Sample Preparation}

Extraction of $\mathrm{BaP}$ and its metabolites was performed using the Ultra-Turrax system (IKA Labortechnik, Germany) and ethyl acetate. To each Erlenmeyer flask, $50 \mathrm{~mL}$ of ethyl acetate was added and the cell biomass was subjected to disintegration at $14,500 \mathrm{rpm}$ for $2 \mathrm{~min}$. The material was transferred to a $125-\mathrm{mL}$ separatory funnel and subjected to vigorous agitation for $1 \mathrm{~min}$. The organic phase was collected and the aqueous phase was again extracted by the addition of $40 \mathrm{~mL}$ of ethyl acetate. In the collected organic phase anhydrous sodium sulfate was added and after filtration the samples were subjected to vacuum rotaevaporator at $45{ }^{\circ} \mathrm{C}$ until reduction of the volume of the sample to approximately $2 \mathrm{~mL}$. The concentrate was transferred to a $10 \mathrm{~mL}$ volumetric flask and diluted with ethyl acetate. An aliquot of $1 \mathrm{~mL}$ of this solution was diluted with another $10 \mathrm{~mL}$ volumetric flask containing $20 \mu \mathrm{g} \mathrm{mL}^{-1}$ of an internal standard solution. The volume of $1 \mu \mathrm{L}$ of the sample was injected into GC-MS.

The internal standard and surrogate solutions were also made up of PAHs with a purity $\geq 98 \%$ (SigmaAldrich, 98 \%) (St. Louis, MO, USA). The internal standard (pyrene) was inserted in the samples diluted in a volumetric flask before injected into GC-MS. The surrogate (chrysene) was inserted in Erlenmeyer flasks before starting the extraction process and contained the same $\mathrm{BaP}$ concentration supplemented in the trials. The use of these patterns is needed to recognize possible losses during the extraction process. Thus, the extraction recovery rate was given by the formula: $\left[\left(A C_{i i} / A C_{i}\right] \times\right.$ 100, where $A C_{i}$ corresponds to the chromatographic area of the internal standard and the $A C_{i i}$ pattern for the chromatographic area of the surrogate. The percentage of $\mathrm{BaP}$ degradation was given by the formula: $\left[\left(c_{i}-\right.\right.$ $\left.\left.c_{r}\right) / c_{i}\right] \times 100$, where $c_{i}$ is the $\mathrm{BaP}$ concentration in the control test and $c_{r}$ the remaining concentration of $\mathrm{BaP}$ from bioassays (Machín-Ramírez et al. 2010). The mean and standard deviation were calculated to higher accuracy of the $\mathrm{BaP}$ concentration obtained after completion of the extraction procedures, chromatographic area of the analyte is corrected by making a calibration curve 
using different $\mathrm{BaP}$ concentrations: 1, 5, 10, 15, 20, 25, and $30 \mu \mathrm{g} \mathrm{L}^{-1}$.

\subsection{CG-MS Analysis}

Analyses were performed on a gas chromatograph (Shimadzu 2010) (Tokyo, Japan) coupled to a mass spectrometer (Shimadzu QP 2010 Plus) and equipped with a Restek fused silica capillary column (RTX-5MS $30 \mathrm{~m} \times 0.25 \mathrm{~mm} \times 0.25 \mu \mathrm{m}$ ) (Bellefonte, PA, USA). The GC temperature program started at $180{ }^{\circ} \mathrm{C}$ and remained for $5 \mathrm{~min}$, followed by a heating rate of $10{ }^{\circ} \mathrm{C} \mathrm{min}{ }^{-1}$ until reaching $295{ }^{\circ} \mathrm{C}$ where it remained for 11 more minutes. The injector temperature was $295{ }^{\circ} \mathrm{C}$ and was in the splitless injection mode, with helium as a carrier gas at a rate of $1.56 \mathrm{~mL} \mathrm{~min}{ }^{-1}$. Mass fragments were recorded by selective ion monitoring (SIM). The ions used were as follows: benzo(a)pireno $(\mathrm{m} / \mathrm{z} 252,250)$, internal standard $(\mathrm{m} / \mathrm{z}, 202,200)$, and surrogate $(\mathrm{m} / \mathrm{z}, 228$, 226).

\subsection{Benzo(a)pyrene Metabolites}

The resulting samples of BaP biodegradation assays were subjected to qualitative analysis to determine the presence of two metabolites recently reported in literature: 1-hydroxy-2-naphthoic acid and coumarin (Table 2) (Hadibarata and Kristanti 2012b). Therefore, the metabolite fragmentation pattern was recorded by the GC-MS and the retention time from injection of standards (Sigma-Aldrich, $\geq 98 \%$ ). The test and standard samples were injected for analysis in the "scan" method with an initial column temperature of $60^{\circ} \mathrm{C}$, remaining for $1 \mathrm{~min}$. The heating rate was $10{ }^{\circ} \mathrm{C} \mathrm{min}{ }^{-1}$ to $280{ }^{\circ} \mathrm{C}$ and remained in isotherm for $10 \mathrm{~min}$. The injector temperature was $280^{\circ} \mathrm{C}$ and the injection mode was splitless, with helium being the carrier gas.

Table 2 Benzo(a)pyrene mass fragment and metabolite retention time

\begin{tabular}{|c|c|c|c|}
\hline Metabolites & $\begin{array}{l}\text { Ion fragments } \\
(\mathrm{m} / \mathrm{z})\end{array}$ & $\begin{array}{l}\text { Retention } \\
\text { time (min) }\end{array}$ & Reference \\
\hline $\begin{array}{l}\text { 1-Hydroxy-2- } \\
\text { naphthoic acid }\end{array}$ & $144,115,58$ & 12.29 & \multirow{2}{*}{$\begin{array}{l}\text { Hadibarata and } \\
\text { Kristanti } \\
(2012 b)\end{array}$} \\
\hline Coumarin & $\begin{array}{c}118,146,89 \\
90,63,45\end{array}$ & 11.24 & \\
\hline
\end{tabular}

\subsection{Statistical Analysis}

The recovery results of the extraction method and rate of biodegradation were expressed as a percentage. To compare the enzymatic activities, variance analysis was applied (one-way ANOVA) followed by Tukey's test at a significance level of $5 \%$ $(p<0.05)$ using the $\mathrm{R}$ program (California, Los Angeles, USA).

\section{Results}

\subsection{Isolation and Screening of Filamentous Fungi}

By means of the Negro River sediment samples, it was possible to obtain 146 filamentous fungi. The region of Panair Port showed the greatest number of isolates (49), highlighting PA2 (21) and PA1 (19), sites that showed considerable contamination by total PAHs ( 892.7 to $995.5 \mathrm{ng} \mathrm{g}^{-1}$ ). The environments with the largest contamination by total PAHs (5273.8 to $2528.5 \mathrm{ng} \mathrm{g}^{-1}$ ) presented a total of 51 isolates distributed among SR1 (15), SR3 (13) CE3 (12), and CE1 (11). The biodegradability test using DCPIP showed positive results for 93 strains $(63.7 \%)$, being eight positive results in $2 \mathrm{~h}, 57$ after $24 \mathrm{~h}$, and 28 after $48 \mathrm{~h}$. Among these fungi, 21 isolates $(22.6 \%)$ had positive responses for the gallic acid reaction (Table 3 ). Most isolates showed brown form quinones (BR) and only four isolates (S06, S29, S42, and S47) were classified with dark brown form quinones (DB). From sampling sites SR1 and CE1, both sites with high contamination by total PAHs (5273.8 to $2375.3 \mathrm{ng} \mathrm{g}^{-1}$ ) and 16 priority PAHs by USEPA (1187-407 $\mathrm{ng} \mathrm{g}^{-1}$ ), seven isolates were capable of oxidizing the gallic acid (S03, S10, S15, S53 and S29, S49, S50, S55). Site PA1, with considerable concentration of total PAHs (892.7 $\mathrm{ng} \mathrm{g}^{-1}$ ) (Souza et al. 2015), showed three isolates (S21, S42, and S47) with positive results (Table 3).

In the assays without the addition of $\mathrm{BaP}$ (Fig. 1a), MnP activity was observed in 10 isolates (S03, S15, S47, S53, S55, S65, S67, S72, S132, and S140) and laccase in only 2 (S10 and S47). Higher $\mathrm{MnP}$ activity was produced by the isolate $\mathrm{S} 132$ $\left(14.96 \pm 5.29 \mathrm{U} \mathrm{L} \mathrm{L}^{-1}\right)$ with a significant difference $(p<0.05)$ from the production by the other isolates. 
Table 3 Gallic acid reaction results and the influence of the absence and presence of benzo(a)pyrene in the production of ligninolytic enzymes

\begin{tabular}{|c|c|c|c|c|c|c|c|c|}
\hline \multirow[t]{2}{*}{ Isolated selected } & \multirow[t]{2}{*}{ Sampling sites } & \multirow[t]{2}{*}{ Gallic acid reaction } & \multicolumn{3}{|c|}{$\mathrm{MEB} 2$ without $\mathrm{BaP}$} & \multicolumn{3}{|c|}{ MEB2 with BaP } \\
\hline & & & Laccase & $\mathrm{LiP}$ & $\mathrm{MnP}$ & Laccase & LiP & $\mathrm{MnP}$ \\
\hline S03 & SR1 & YB & - & - & + & - & - & - \\
\hline S06 & IR1 & DB & - & - & - & - & - & - \\
\hline S10 & SR1 & YB & + & - & - & + & - & - \\
\hline S11 & IR1 & $\mathrm{BR}$ & - & - & - & - & - & + \\
\hline S15 & SR1 & YB & - & - & + & + & - & - \\
\hline S21 & PA1 & $\mathrm{BR}$ & - & - & - & - & - & - \\
\hline S29 & CE1 & DB & - & - & - & - & - & - \\
\hline S42 & PA1 & DB & - & - & - & + & - & - \\
\hline S47 & PA1 & DB & + & - & + & + & - & + \\
\hline $\mathrm{S} 50$ & CE1 & $\mathrm{BR}$ & - & - & - & - & - & + \\
\hline S53 & SR1 & $\mathrm{BR}$ & - & - & + & - & - & + \\
\hline S55 & CE1 & BR & - & - & + & - & - & - \\
\hline S65 & PA2 & BR & - & - & + & - & - & - \\
\hline S67 & CE2 & BR & - & - & + & - & - & + \\
\hline S69 & CE2 & BR & - & - & - & - & - & + \\
\hline S72 & CE2 & BR & - & - & + & - & - & + \\
\hline $\mathrm{S} 123$ & SR3 & BR & - & - & - & - & - & + \\
\hline S125 & SR3 & YB & - & - & - & - & - & - \\
\hline S132 & IR3 & BR & - & - & + & - & - & + \\
\hline S140 & MM3 & BR & - & - & + & - & - & + \\
\hline S143 & CE3 & BR & - & - & - & - & - & - \\
\hline
\end{tabular}

$D B$ dark brown, $B R$ brown, $Y B$ yellowish brown, + presence of enzyme activity, - absence of enzyme activity, MEB $2 \%$ Agar Malt Extract $2 \%$

Laccase activity was low and non-existent for most isolates, being the highest activity $(3.82 \pm$ $0.99 \mathrm{U} \mathrm{L}^{-1}$ ) produced by the isolate $\mathrm{S} 47$. In the assays supplemented with $\mathrm{BaP}$ (Fig. 1b), four isolates (S10, S15, S42, and S47) presented positive response for laccase activity, suggesting that the xenobiotic served as inductor to increase the activity of this enzyme. The isolate S47 $(22: 15 \pm 5.39)$ produced the highest amount of laccase $(p<0.05)$. Another 10 isolates (S11, S47, S50, S53, S67, S69, $\mathrm{S} 72, \mathrm{~S} 123, \mathrm{~S} 132$, and S140) were able to produce $\mathrm{MnP}$. The presence of $\mathrm{BaP}$ resulted in different responses in $\mathrm{MnP}$ activity among the isolates: decrease (S132 and S72); inhibition (S03, S15, S55 and S65), increase (S47, S49, S53, S67, and S140), and induction (S11, S50, S69, and S123). The isolate S69 stood out with the highest activity (30.20 \pm 8:54 U L-1) $(p<0.05)$ (Fig. 1). There was no LiP activity (Table 3 ). Based on these results, the isolates S47 and S69 were selected and submitted to the $\mathrm{BaP}$ biodegradation assays.

\subsection{Taxonomic Identification of Selected Fungi}

Following a morphological examination of isolates S47 and $\mathrm{S} 69$ no reproductive structures could be found in the cultures even after one-month growth in MA2\% plates. ITS sequencing revealed Megasporoporia sp. (accession \#: KP013029) as the closest related fungus for isolate S47 with $97 \%$ of similarity. For isolate S69 the closest related fungus was an unidentified Sordariales species (accession \#: AB986410) with $91 \%$ of similarity. Because of the low similarity with homologous sequences and the absence of reproductive structures, strain S69 was considered as an unidentified fungus from the Sordariales order and may represent a putative new species. 
Fig. 1 Production of ligninolytic enzymes by filamentous fungi in the absence (a) and presence (b) of benzo(a)pyrene. The vertical bars show the standard error. Different letters are significantly different at $p<0.05$ by Tukey's test
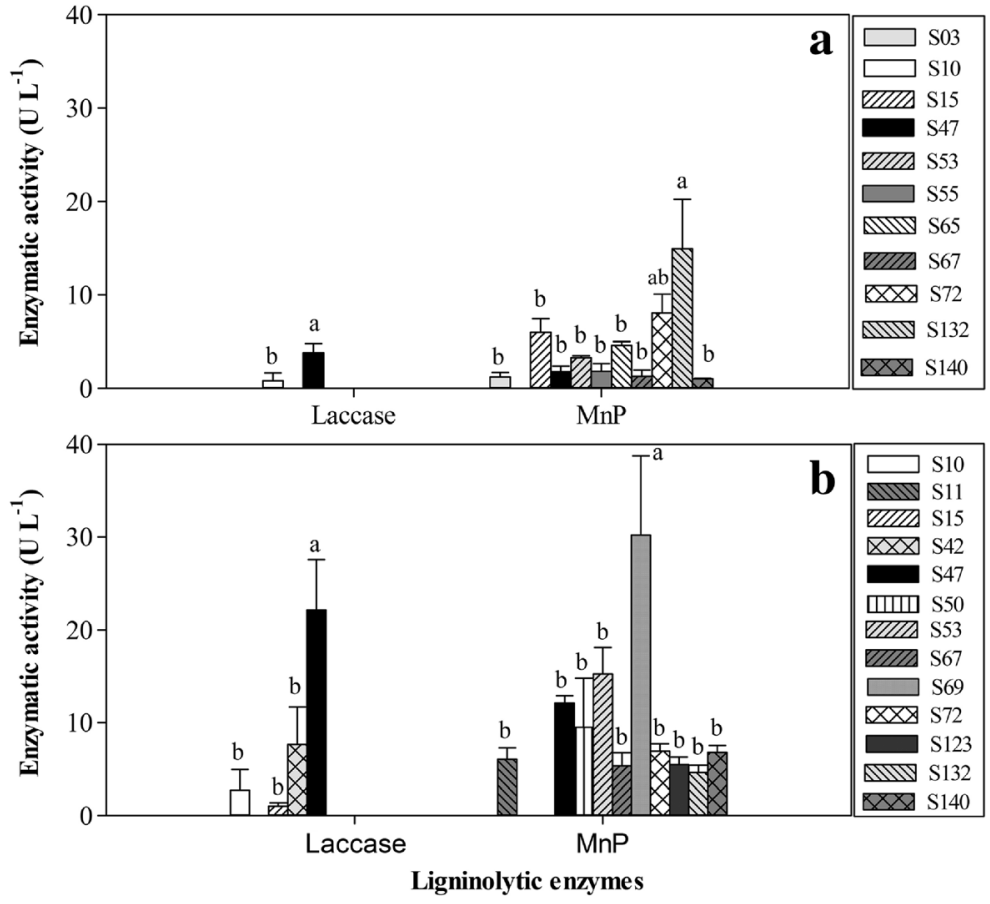

had the ability to perform diesel hydrocarbon oxidation. The positive results were faster than some cited in

The $\mathrm{BaP}$ biodegradation potential by the selected fungi is shown in Fig. 2. In assay I, Megasporoporia sp. S47 showed a degradation rate of $49.9 \pm 0.6 \%$ over a period of 7 days and $54.4 \pm 3.6 \%$ after 14 days. Unidentified Sordariales S69 degraded only $28.2 \pm 0.5 \%$. In assay II, the results were similar, confirming the greatest potential of Megasporoporia sp. S47 for biodegradation, which reached a maximum degradation of $36.5 \pm 5.3 \%$ at the end of the experiment. Unidentified Sordariales S69 degraded only $17.2 \pm 9.3 \%$. The chromatogram of $\mathrm{BaP}$ degradation by Megasporoporia sp. S47 is shown in Fig. 3. The recovery of the extraction method ranged from 75.5 to $\geq 99 \%$. The metabolites (1-hydroxy-2naphthoic acid and coumarin) were not identified in the $\mathrm{BaP}$ biodegradation samples.

\section{Discussion}

The selection of microorganisms that have potential for PAH degradation is a key step in bioremediation programs. Therefore, combining information obtained in different screening tests is essential. In this study, the biodegradability test using the DCPIP redox indicator allowed us to quickly recognize the fungal isolates that
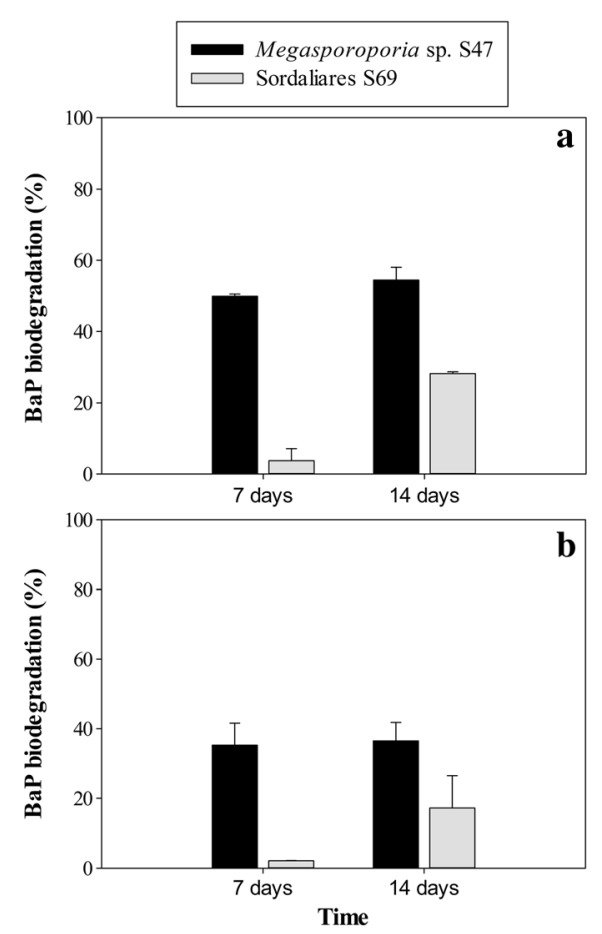

Fig. 2 Benzo(a)pyrene biodegradation by filamentous fungi isolated from samples of the Amazon region. a Assay supplemented with $1 \mathrm{mg}$ of $\mathrm{BaP}$ and $\mathbf{b}$ assay supplemented with $2 \mathrm{mg}$ of $\mathrm{BaP}$ 


\section{a}

\section{b}

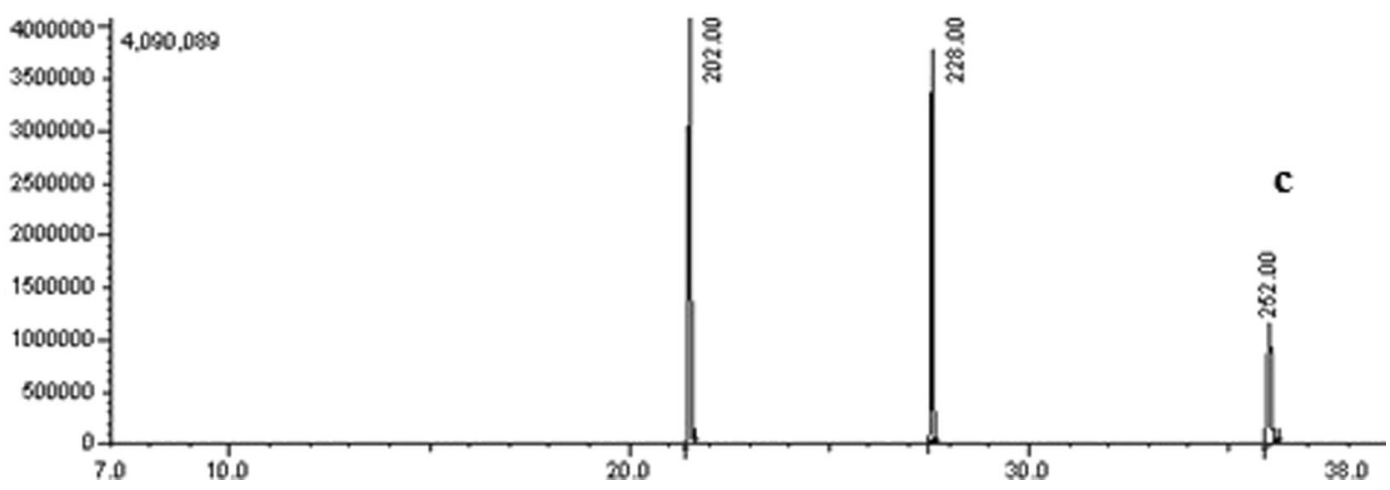

Fig. 3 Chromatogram related to benzo(a)pyrene biodegradation by Megasporoporia sp. S47. (a) pyrene $(\mathrm{m} / \mathrm{z}, 202,200) ;(b) \mathrm{chrysene}(\mathrm{m} / \mathrm{z}$ $228,226)$; and $(c)$ benzo(a)pyrene $(\mathrm{m} / \mathrm{z} 252,250)$ after biodegradation

literature (Mariano et al. 2007, 2008). This may possibly be related to the presence of extracellular enzymes that remain in the culture used in the experiments. The results indicate that the method is effective for initial tests and quick for the selection of fungi with potential for hydrocarbon degradation.

The gallic acid reaction is a simple and convenient qualitative method that has been recommended in literature as the best indicator, compared with the use of Remazol Brilliant Blue R (RBBR) dye and tolerance tests to classify fungi by its ability to degrade xenobiotics (Lee et al. 2014). Gallic acid is a natural reagent that when oxidized by the action of the phenoloxidase enzymes form quinones, yielding a brown halo around the mycelium (Erden et al. 2009). In this paper, the use of this technique resulted in the selection of $22.6 \%$ of the fungal isolates, which was similar to other researchers related to the selection of ligninolytic (basidiomycetes) and non-ligninolytic fungi with abilities to proceed in studies on PAHs biodegradation (Conceição et al. 2005; Lee et al. 2014).

Together with the application of the aforementioned qualitative tests, it is necessary to evaluate the production of microbial ligninolytic enzymes, since these enzymes are directly involved in the degradation of several recalcitrant phenolic compounds (Sette et al. 2008; Harms et al. 2011). The ability of fungi to produce ligninolytic enzymes in malt extract with the presence or absence of inducing substrates (Bonugli-Santos et al. 2009) and in the presence of diesel oil (Maciel et al. 2010) has been reported. The best results have been observed to the basidiomycetes fungi in regard to the production of these enzymes and their relationship to the discoloration of the RBBR dye (Bonugli-Santos et al. 2012; Machado et al. 2005) and to degrade PAHs, such as phenanthrene, pyrene, anthracene, benzo(a)anthracene, and benzo(a)pyrene (Wu et al. 2010; Ting et al. 2011; Hadibarata and Kristanti 2012a).

In the present study, there was low production of ligninolytic enzymes. However, it was enough to show that some fungal isolates are able to express these enzymes. The use of malt extract to evaluate the activity of ligninolytic enzymes has being carried out because this medium is rich in tryptophan, aromatic amino acids, and tyrosine (Arora and Gill 2001). However, for screening of species that are effective in PAH degradation, conducting enzyme assays without the presence of the substrate of interest has been cited as inadvisable (Lee et al. 2014). It is necessary to take into consideration that aromatic compounds and synthetic dyes can act as agents responsible for the regulation and manifestation of these enzymes (Yang et al. 2011; Casas et al. 2013). This fact corroborates the results obtained in this study, where it was observed that the highest laccase activity and $\mathrm{MnP}$ occurred in assays supplemented with $\mathrm{BaP}$ (Table 3).

Data from literature showed that the increased activity of ligninolytic enzymes (especially $\mathrm{MnP}$ and laccase) by the white-rot fungi of the genera Armillaria, Anthracophyllum, Polyporus, and some leaf litter decomposers, is directly related to the degradation of high molecular weight PAHs (Steffen et al. 2003; Acevedo et al. 2011; Hadibarata et al. 2009; Hadibarata and Kristanti 2012a, b). These enzymes are proving to be key enzymes in PHAs degradation process. Among the fungi selected in this study Megasporoporia sp. S47, a 
white-rot fungus from Polyporaceae family, proved to be the most promising. The fungus was able to produce higher amounts of laccase in the presence of the xenobiotic and showed higher potential to $\mathrm{BaP}$ biodegradation, supporting the literature findings that indicate a direct relationship between laccases and $\mathrm{BaP}$ degradation. Currently, it is known that the regulation of the laccase transcription can be different for each species of fungus (Rivera-Hoyos et al. 2013); thus, new studies about laccase production by Megasporoporia sp. S47, as well as it purification and characterization are needed to determine the potential of the fungus/enzyme for being used in industrial bioprocesses and future applications in bioremediation.

The Megasporoporia genus Ryvarden \& JE Wright was described by Ryvarden et al. (1982) based on Poria setulosa Henn. Representatives of this genus are characterized by having ressupinated basidiocarps containing large or small pores, basidiospores often exceeding $10 \mathrm{~mm}$ in length, occurring mainly in angiosperm branches and causing white rot (Ryvarden et al. 1982; $\mathrm{Li}$ and Cui 2013). These are fungi from the Polyporales order, Polyporaceae family. In the state of Amazonas, a representative of this genus, Megasporoporia cavernulosa (Berk.) Ryvarden, was already reported by Gomes-Silva and Gibertoni (2009). In the present study, Megasporoporia sp. S47 was obtained from the sediment collected at the Negro River in the Amazon, located in a popular port area mainly built with wood. Since representatives of this genus are able to degrade wood, it is reasonable to believe that pieces of timber in this region are the colonization source of these kind of fungi. Furthermore, there is some plant material in the sediments that can be transported and deposited on the bottom. Although a wide variety of white-rot fungi is capable of degrading low molecular weight PAHs such as anthracene and phenanthrene, literature reports the existence of few genus that degrade BaP (Juhasz and Naidu 2000). It is important to highlight that to our knowledge there is no data in the literature related to the $\mathrm{BaP}$ degradation by representatives of the genus Megasporoporia, been this study the first one to report this source of data. However, other representatives of the Polyparaceae family, such as Polyporus sp., are known as efficient decomposers of the chrysene and BaP (Hadibarata et al. 2009; Hadibarata and Kristanti 2012a).

In the present study, results of the biodegradation assays suggest that Megasporoporia sp. S47 is a promising species in degrading HMW PAHs, since in 14 days
$54 \%$ of $\mathrm{BaP}$ was degraded. In the literature, $\mathrm{BaP}$ degradation has been reported by ligninolytic and non ligninolytic fungi. Passarini et al. (2011a) showed that Aspergillus sclerotiorum and Mucor racemosus (non ligninolytic fungi) were able to degrade 51.7 to $76.6 \%$ $\mathrm{BaP}$, respectively, after 16 days of incubation. Wu et al. (2010) reported $60 \%$ of benzo(a)anthracene degradation by Fusarium solani in a period of 40 days. Among the ligninolytic fungi (white-rot basidiomycetes), Polyporus sp. and Armillaria sp. presented high potential for $\mathrm{BaP}$ degradation, reaching between 73 and $76 \%$ after 30 days of incubation. The use of energetic substrates in these studies showed an increasing in the degradation by cometabolism (Hadibarata and Kristanti 2012a, b).

It is important to mention that the potential of PAHs biodegradation can be maximized by the otimization of some parameters such as temperature, $\mathrm{pH}$, carbon and nitrogen sources, and by the use of inductors. Another factor that influences the xenobiotic degradation process is the toxicity of the compound. Since $\mathrm{BaP}$ is toxic, mutagenic and carcinogenic, and seeing that it is known that Megasporoporia sp. S47 has degradation abilities, further studies are necessary to evaluate the degradation process over a longer time period and diversifying the compound concentration.

PAH metabolites originating from fungi of white rot (ligninolytic) are generally quinone (Volkering and Breure 2003). In a recent study, Hadibarata and Kristanti (2012a) evaluated BaP degradation by Polyporus sp. S133 and suggested that laccase and 1.2-dioxygenase have an important role in $\mathrm{BaP}$ transformation. Polyporus sp. S133 transformed BaP into BaP1.6-quinone, which is degraded in two other ways, forming 1-hydroxy-2-naphthoic acid, and coumarin. The presence of these metabolites indicates the possibility of cleavage forming benzoic acid, which can also be degraded by the formation of tricarboxylic acid, followed by mineralization.

In this study, the analysis of BaP metabolites reported by Hadibarata and Kristanti (2012a) was not identified. However, considering that Megasporoporia sp. S47 belongs to the ligninolytic group of fungi (white hot) and that laccase production was induced by the presence of $\mathrm{BaP}$ it is probable that this fungus carry out a similar method for HPAs degradation like Polyporus sp. S133. Therefore, further studies on the production of metabolites must be performed in order to confirm this similarity between fungi of the same taxonomic family. 
Megasporoporia sp. S47 and Unidentified Sordariales S69 selected in this study were obtained from environments with considerable contamination of total PAHs (PA1 and CE2) (Table 1). Fungi isolated from environments with high PAHs contamination showed no potential for BaP degradation. Probably the fungi from these sites are tolerant to the presence of PAHs, but do not have the ability to degrade them. It is also necessary to take into consideration the special conditions of the Negro River sediments regarding their granulometry, as mentioned by Souza et al. (2015), and the small amounts of substrates for fungal colonization. Gomes et al. (2011) and Da Silva et al. (2003) reported that the diversity of substrates and nutrient availability are abiotic factors that determine the presence, permanence and survival of mycobiota. It is important to mention that of the 21 isolates selected for their oxidation capacity of gallic acid, nine isolates ( $\mathrm{S} 03, \mathrm{~S} 10, \mathrm{~S} 15$, S29, S50, S55, S123, S125, S143) belong to the regions of Porto São Raimundo and Ceasa, regions characterized by Souza et al. (2015) to be highly contaminated. Among these isolates, three (S03, S15 and $\mathrm{S} 55)$ showed MnP production and one isolate ( 10 ) produced laccase in MEB $2 \%$. In the presence of $\mathrm{BaP}$, this production was completely inhibited. Although the production of these enzymes was much smaller than that found in the isolates selected in this study, it is possible to advise that further studies should also be carried out with these isolates in order to check for increased production of these enzymes in optimal conditions and using other PAHs with smaller toxicity.

\section{Conclusion}

The approaches used in this study were effectives and enabled the selection of the white-rot fungus Megasporoporia sp. S47, which in the presence of $\mathrm{BaP}$, increased the production of laccase and $\mathrm{MnP}$ and presented a great ability to degrade this recalcitrant environmental pollutant. There are no data in the consulted literature related to the potential of $\mathrm{BaP}$ degradation by representatives of the genus Megasporoporia; therefore, the fungus Megasporoporia sp. S47 can be considered as a promising genetic resource for future studies related to the optimization of culture conditions targeting the increase of the enzymatic production and PAHs degradation rates. Additionally, this study also demonstrates the importance of the microbial selection stage, even to those collected in areas contaminated with PAHs, ensuring the obtainment of genetically promising species for biodegradation of environmental pollutants with a view to their use in bioremediation programs.

Acknowledgments The authors are grateful to the National Council for Scientific and Technological Development (CNPq) and Federal Agency for the Support and Evaluation of Graduate Education (CAPES), both Brazilian Government institutions, for their financial support. The first author also is grateful to Post Graduate Program in Biodiversity and Biotechnology of the Legal Amazon (Bionorte Network).

\section{References}

Acevedo, F., Pizzul, L., Castello, M. P., Cuevas, R., \& Diez, M. C. (2011). Degradation of polycyclic aromatic hydrocarbons by the Chilean white-rot fungus Anthracophyllum discolor. Journal of Hazardous Materials, 185(1), 212-219.

Almeida, F. V., Centeno, A. J., Bisinoti, M. C., \& Jardim, W. F. (2007). Substâncias tóxicas persistentes (STP) no Brasil. Quim Nova, 30(8), 1976-1985.

Argumedo-Delira, R., Alarcón, A., Ferrera-Cerrato, R., Almaraz, J. J., \& Peña-Cabriales, J. J. (2012). Tolerance and growth of 11 Trichoderma strains to crude oil, naphthalene, phenanthrene and benzo[a]pyrene. Journal of Environmental Management, 95, S291-S299.

Arora, D. S., \& Gill, P. K. (2001). Comparison of two assay procedure for lignin peroxidase. Enzyme and Microbial Technology, 28, 602-605.

Bícego, M. C., Taniguchi, S., Yogui, G. T., Montone, R. C., Silva, D. A. M., Lourenço, R. A., Martins, C. C., Sasaki, S. T., Pellizari, V. H., \& Weber, R. R. (2006). Assessment of contamination by polychlorinated biphenyls and aliphatic and aromatic hydrocarbons in sediments of the Santos and São Vicente Estuary System, São Paulo, Brazil. Marine Pollution Bulletin, 52, 1784-1832.

Bonugli-Santos, R. C., Durrant, L. R., Da Silva, M., \& Sette, L. D. (2009). Production of laccase, manganese peroxidase and lignin peroxidase by Brazilian marine-derived fungi. Enzyme and Microbial Technology, 46, 32-37.

Bonugli-Santos, R. C., Durrant, L. R., \& Sette, L. D. (2012). The production of ligninolytic enzymes by marine-derived basidiomycetes and their biotechnological potential in the biodegradation of recalcitrant pollutants and the treatment of textile effluents. Water, Air, and Soil Pollution, 223, 2333-2345.

Brito, E. M. S., Vieira, E. D. R., Torres, J. P. M., \& Malm, O. (2005). Persistent organic pollutants in two reservoirs along the Paraíba do Sul-Guandú River system, Rio de Janeiro, Brazil. Quim Nova, 28, 941-946.

Buswell, J. K., Cai, Y. J., \& Chang, S. T. (1995). Effect of nutrient nitrogen on manganese peroxidase and lacase production by Lentinula (Lentinus) edodes. FEMS Microbiology Letters, 128, 81-88. 
Casas, N., Blánquez, P., Vicent, T., \& Sarrà, M. (2013). Laccase production by Trametes versicolor under limited-growth conditions using dyes as inducers. Environmental Technology, 34, 113-119.

Castellani, A. (1939). The viability of some pathogenic fungi in sterile distilled water. The Journal of Tropical Medicine and Hygiene, 42, 225-226.

Cerniglia, C. E. (1992). Biodegradation of polycyclic aromatic hydrocarbons. Biodegradation, 3, 351-368.

Cerniglia, C. E., \& Sutherland, J. B. (2010). Degradation of polycyclic aromatic hydrocarbons by fungi, 2010. In K. N. Timmis (Ed.), Handbook of hydrocarbon and lipid microbiology (pp. 2079-2110). Berlin: Springer.

Colla, L. M., Primaz, A. L., Lima, M., Bertolin, T. E., \& Costa, J. A. V. (2008). Isolamento e seleção de fungos para biorremediação a partir de solo contaminado com herbicida triazínicos. Ciência e Agrotecnologia, 32, 809-813.

Conceição, D. M., Angelis, D. A., Bidoia, B. D., \& Angelis, D. F. (2005). Fungos filamentosos isolados do Rio Atibaia SP e refinaria de petróleo biodegradadores de compostos fenólicos. Arquivos do Instituto Biológico, 72, 99-106.

Da Silva, M., Umbuzeiro, G. A., Pfenning, L. H., Canhos, V. P., \& Esposito, E. (2003). Filamentous fungi isolated from estuarine sediments contaminated with industrial discharges. Soil and Sediment Contamination, 12, 345-356.

Erden, E., Ucar, M. C., Gezer, T., \& Pazarlioglul, N. K. (2009). Screening for ligninolytic enzymes from autochthonous fungi and applications for decolorization of Remazole Marine Blue. Brazilian Journal of Microbiology, 40, 346-353.

Gerardo, N. M., Muller, V. G., Price, S. L., \& Currie, C. R. (2004). Exploiting a mutualism: parasite specialization on cultivars within the fungus-growing ant symbiosis. Proceedings of the Royal Society B, 271, 1791-1798.

Giardina, P., Palmieri, G., Fontanella, B., Rivieccio, V., \& Sannia, G. (2000). Manganese peroxidase isoenzymes produced by Pleurotus ostreatus grown on wood sawdust. Archives of Biochemistry and Biophysics, 376, 171-179.

Gomes, D. N. F., Cavalcanti, M. A. Q., \& Passavante, J. Z. O. (2011). Fungos filamentosos isolados de sedimentos do manguezal Barra das Jangadas, Jaboatão dos Guararapes, Pernambuco, Brasil. Tropical Oceanography, 39, 36-45.

Gomes-Silva, A. C. \& Gibertoni, T. B. (2009). Checklist of the aphyllophoraceous fungi (Agaricomycetes) of the Brazilian Amazonian. Mycotaxon, 108, 319-322.

Hadibarata, T., \& Kristanti, P. A. (2012a). Identification of metabolites from benzo(a)pyrene oxidation by ligninolytic enzymes of Polyporus sp. S133. Journal of Environmental Management, 111, 115-119.

Hadibarata, T., \& Kristanti, P. A. (2012b). Fate and cometabolic degradation of benzo[a]pyrene by white-rot fungus Armillaria sp. F022. Bioresource Technology, 107, 314-318.

Hadibarata, T., Tachibana, S., \& Itoh, K. (2009). Biodegradation of chrysene, an aromatic hydrocarbon by Polyporus sp. S133 in liquid medium. Journal of Hazardous Materials, 164, 911-917.

Hanson, K. G., Desai, J. D., \& Desai, A. J. A. (1993). Rapid and simple screening technique for potential crude oil degrading microorganisms. Biotechnology Techniques, 7, 745-748.

Haritash, A. K., \& Kaushik, C. P. (2009). Biodegradation aspects of Polycyclic Aromatic Hydrocarbons (PAHs): a review. Journal of Hazardous Materials, 169, 1-15.
Harms, H., Schlosser, D., \& Wick, L. Y. (2011). Untapped potential: exploiting fungi in bioremediation of hazardous chemicals. Nature Reviews Microbiology, 9, 177-191.

International Agency for Research on Cancer (IARC). (1983). IARC monographs on the evaluation of the carcinogenic risk of chemicals to humans, polynuclear aromatic compounds, Part 1, chemical, environmental and experimental data, 32. Lyon: International Agency for Research on Cancer.

Jennings, A. A. (2012). Worldwide regulatory guidance values for surface soil exposure to carcinogenic or mutagenic polycyclic aromatic hydrocarbons. Journal of Environmental Management, 110, 82-102.

Juhasz, A. L., \& Naidu, R. (2000). Bioremediation of high molecular weight polycyclic aromatic hydrocarbons: a review of the microbial degradation of benzo[a]pyrene. International Biodeterioration and Biodegradation, 45, 57-88.

Lee, H., Jang, Y., Choi, Y.-S., Kim, M.-J., Lee, J., Lee, H., Hong, J.-H., Lee, Y. M., Kim, G.-H., \& Kim, J.-J. (2014). Biotechnological procedures to select white rot fungi for the degradation of PAHs. Journal of Microbiological Methods, 97, 56-62.

Leite, N. F., Peralta-Zamora, P., \& Grassi, M. T. (2011). Distribution and origin of polycyclic aromatic hydrocarbons in surface sediments from an urban river basin at the Metropolitan Region of Curitiba, Brazil. Journal of Environmental Sciences, 23, 904-911.

Lemos, J. L. S., Barros, C. A., Oliveira, S. D., \& Reiche, A. P. (2008). Fungos filamentosos: Agentes de degradação de petróleo e de hidrocarbonetos aromáticos policíclicos (HAPs). Rio de Janeiro: CETEM/MCT. 58p. (Série Tecnologia Ambiental, 46).

Li, H., \& Cui, B. (2013). Taxonomy and phylogeny of the genus Megasporoporia and its related genera. Mycologia, 105, 368-383.

Machado, K. M. G., Matheus, D. R., \& Bononi, V. L. R. (2005). Ligninolytic enzymes production and Remazol Brilliant Blue $\mathrm{R}$ decolorization by tropical Brazilian basidiomycetes fungi. Brazilian Journal of Microbiology, 36, 246-252.

Machín-Ramírez, C., Morales, D., Martínez-Morales, F., Okoh, A. I., \& Trejo-Hernández, M. R. (2010). Benzo[a]pyrene removal by axenic- and co-cultures of some bacterial and fungal strains. International Biodeterioration and Biodegradation, 64, 538-544.

Maciel, C. C. S., Souza, M. A., Gusmão, N. B., \& Campos-Takaki, G. M. (2010). Produção de enzimas do sistema ligninolítico por fungos filamentosos isolados de locais impactados por petroderivados. Exacta, 8, 299-305.

Mackay, D., \& Fraser, A. (2000). Bioaccumulation of persistent organic chemicals: mechanisms and models. Environmental Pollution, 110, 375-391.

MähnB, B., Stehr, F., Schäfer, W., \& Neuber, K. (2005). Comparison of standard phenotypic assays with a PCR method to discriminate Candida albicans and C. dubliniensis. Mycoses, 48, 55-61.

Mariano, A. P., Angelis, D. de F., \& Bonotto, D. M. (2007). Monitoramento de indicadores geoquímicos e avaliação da degradação em área contaminada com óleo diesel. Engenharia Sanitaria e Ambiental, 12, 296-304.

Mariano, A. D., Bonoto, D. M., Angelis, D. F., Pirôllo, M. D. S., \& Contiero, J. (2008). Biodegradability of commercial and 
weathered diesel oils. Brazilian Journal of Microbiology, 39, $133-142$.

Meire, R. O., Azeredo, A., Pereira, M. S., \& Torre, J. P. M. (2008). Polycyclic aromatic hydrocarbons assessment in sediment of national parks in the southeast Brazil. Chemosphere, 73, 180-185.

Moeller, E. M., Bahnweg, G., Sandermann, H., \& Geiger, H. H. (1992). A simple and efficient protocol for isolation of high molecular weight DNA from filamentous fungi fruit bodies and infected plant tissues. Nucleic Acids Research, 20, 61156116.

Muncnerová, D., \& Augustin, J. (1994). Fungal metabolism and detoxification of polycyclic aromatic hydrocarbons: a review. Bioresource Technology, 48, 97-106.

Netto, A. D. P., Moreira, J. C., Dias, A. E. X. O., Arbilla, G., Ferreira, L. F. V., Oliveira, A. S., \& Barek, J. (2000). Avaliação da contaminação humana por Hidrocarbonetos Policíclicos Aromáticos (HPAS) e seus derivados nitrados (NHPAS): uma revisão metodológica. Quim Nova, 23, 765773.

Passarini, M. R. Z., Sette, L. D., \& Rodrigues, M. V. N. (2011a). Improved extraction method to evaluate the degradation of selected PAHs by marine fungi grown in fermentative medium. Journal of the Brazilian Chemical Society, 22, 564-570.

Passarini, M. R. Z., Rodrigues, M. V. N., Silva, M., \& Sette, L. D. (2011b). Marine derived filamentous fungi and their potential application for polycyclic aromatic hydrocarbon bioremediation. Marine Pollution Bulletin, 62, 364-370.

Perelo, L. W. (2010). Review: in situ and bioremediation of organic pollutants in aquatic sediments. Journal of Hazardous Materials, 177, 81-89.

Ravelet, C., Krivobok, S., Sage, L., \& Steiman, R. (2000). Biodegradation of pyrene by sediment fungi. Chemosphere, 40, 557-563.

Rivera-Hoyos, C. M., Morales-Alvarez, E. D., Potou-Piñales, R. A., Pedroza-Rodríguez, A. M., Rodríguez-Vázquez, R., \& Delgado-Boada, J. M. (2013). Fungal laccases. Fungal Biology Reviews, 27, 67-82.

Ryvarden, L., Wright, J. E., \& Rajchenberg, M. (1982). Megasporoporia a new genus of resupinate polypores. Mycotaxon, 16, 172-182.
Sette, L. D., Oliveira, V. M., \& Rodrigues, M. F. A. (2008). Microbial lignocellulolytic enzymes: industrial applications and future perspectives. Microbiology Australia, 29, 18-20.

Souza, H. M. L., Taniguchi, S., Bícego, M. C., Oliveira, L. A., Oliveira, T. C. S., Barroso, H. S., \& Zanotto, S. P. (2015). Polycyclic aromatic hydrocarbons in superficial sediments of the Negro River in the Amazon Region of Brazil. Journal of the Brazilian Chemical Society, 26, 1438-1449.

Steffen, K. T., Hatakka, A., \& Hofrichter, M. (2003). Degradation of benzo(a)pyrene by the litter-decomposing basidiomycete Stropharia coronilla: role of manganese peroxidase. Applied and Environmental Microbiology, 69, 3957-3964.

Ting, W. T. E., Yuan, S. Y., Wu, S. D., \& Chang, B. V. (2011). Biodegradation of phenanthrene and pyrene by Ganoderma lucidum. International Biodeterioration and Biodegradation, 65, 238-242.

Volkering, F., \& Breure, A. M. (2003). Biodegradation and general aspects of bioavailability. In P. E. T. Douben (Ed.), PAHs: an ecotoxicological perspective. Chichester: John Wiley \& Sons, Ltd. doi:10.1002/0470867132.ch6.

White, T. B., \& Lee, S. (1990). Amplification and direct sequencing of fungal ribosomal RNA genes for phylogenetics. In M. A. Innis, D. H. Gelfand, J. J. Sninsky, \& T. J. White (Eds.), PCR protocols: a guide to methods and applications (pp. 315-322). San Diego: Academic.

Wu, Y.-R., Luo, Z.-H., \& Vrijmoed, L. L. P. (2010). Biodegradation of anthracene and benz[a]anthracene by two Fusarium solani strains isolated from mangrove sediments. Bioresource Technology, 101, 9666-9672.

Yang, Y., Ma, F., Yu, H., Fan, F., Wan, X., Zhang, X., \& Jiang, M. (2011). Characterization of a laccase gene from the white-rot fungi Trametes sp. 5930 isolated from Shennongjia Nature Reserve in China and studying on the capability of decolorization of different synthetic dyes. Biochemical Engineering Journal, 57, 13-22.

Zafra, G., Absalón, A. E., Cuevas, M. D. C., \& Córtes-Espinosa, C. (2014). Isolation and selection of a highly tolerant microbial consortium with potential for PAH biodegradation from heavy crude oil-contaminated soils. Water, Air, and Soil Pollution, 225, 1826. 